\title{
Infographic: vitrectomy plus encircling band vs. vitrectomy alone for the treatment of pseudophakic retinal detachment (VIPER) study
}

\author{
Alexander Mehta $\mathbb{D}^{1} \cdot$ Salman Sadiq ${ }^{1} \cdot$ Nikolaos Tzoumas $^{1} \cdot$ Anna Song $^{1}{ }^{1} \cdot$ Declan Murphy $^{1}{ }^{1} \cdot$ Islam $^{\text {Mostafa }}{ }^{1} \cdot$ \\ Ali Ghareeb ${ }^{1} \cdot$ Mohaimen Al-Zubaidy ${ }^{1} \cdot$ David Steel $^{1}{ }^{1}$
}

Received: 20 March 2021 / Revised: 26 March 2021 / Accepted: 31 March 2021 / Published online: 26 May 2021

(c) The Author(s) 2021. This article is published with open access

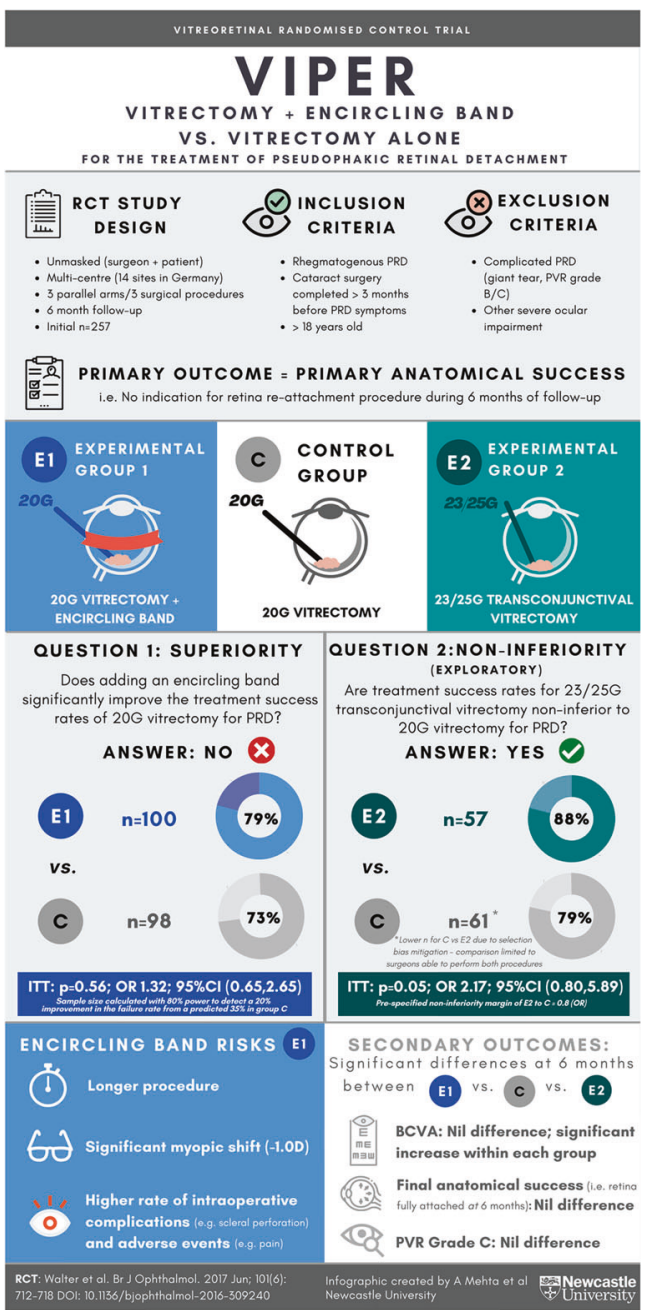

David Steel

david.steel@ncl.ac.uk

1 Bioscience Institute, Newcastle University, Newcastle Upon Tyne, UK
Fig. 1 The Vitrectomy Plus Encircling Band vs. Vitrectomy Alone for the Treatment of Pseudophakic Retinal Detachment (VIPER) randomised control trial showed that performing scleral buckling in addition to vitrectomy does not significantly reduce the risk of follow-up retinal reattachment surgery. For management with vitrectomy alone, small gauge transconjunctival vitrectomy $(23 / 25 \mathrm{G})$ is not inferior to the conventional $20 \mathrm{G}$ technique. RCT randomised control trial, PRD pseudophakic retinal detachment, ITT intention to treat, OR odds ratio, CI confidence interval, BCVA best corrected visual acuity, PVR proliferative vitreoretinopathy.

Reference to original study: Walter $\mathrm{P}$, Hellmich $\mathrm{M}$, Baumgarten S, Schiller P, Limburg E, Agostini $\mathrm{H}$ et al. Vitrectomy with and without encircling band for pseudophakic retinal detachment: VIPER Study Report No 2-main results. Br J Ophthalmol 2017; 101(6):712-718.

\section{Compliance with ethical standards}

Conflict of interest The authors declare no competing interests.

Publisher's note Springer Nature remains neutral with regard to jurisdictional claims in published maps and institutional affiliations.

Open Access This article is licensed under a Creative Commons Attribution 4.0 International License, which permits use, sharing, adaptation, distribution and reproduction in any medium or format, as long as you give appropriate credit to the original author(s) and the source, provide a link to the Creative Commons license, and indicate if changes were made. The images or other third party material in this article are included in the article's Creative Commons license, unless indicated otherwise in a credit line to the material. If material is not included in the article's Creative Commons license and your intended use is not permitted by statutory regulation or exceeds the permitted use, you will need to obtain permission directly from the copyright holder. To view a copy of this license, visit http://creativecommons. org/licenses/by/4.0/. 